\title{
At odds over big science
}

\section{Tokyo}

US AND Japanese government officials met in Tokyo last week for a marathon five-day session - to discuss collaboration between the two countries. The main conclusion to be drawn is that as long as the two countries stay with small joint projects, they work well together. But attempts to launch 'big science' projects are still having considerable difficulty getting off the ground. The five-day working-level meeting, held under the auspices of the 1988 US-Japan Science and Technology Agreement, drew a US delegation of twenty, led by John P. Boright deputy assistant secretary of state for oceans and international affairs.

The two countries agreed to start 33 new joint projects in the six fields covered JAPAN

\section{Microgravity on tap}

\section{Tokyo}

OFFiCIALS of the Ministry of International Trade and Industry (MITI) gathered in Japan's northern island of Hokkaido last week to watch a 5-ton capsule being dropped nearly a kilometre down an old coalmine shaft. A bowl of goldfish in the rocket-shaped capsule experienced a momentary spell of near-zero gravity. The experiment, which caused some of the goldfish to swim upside down, marked the opening of the world's most advanced microgravity centre.

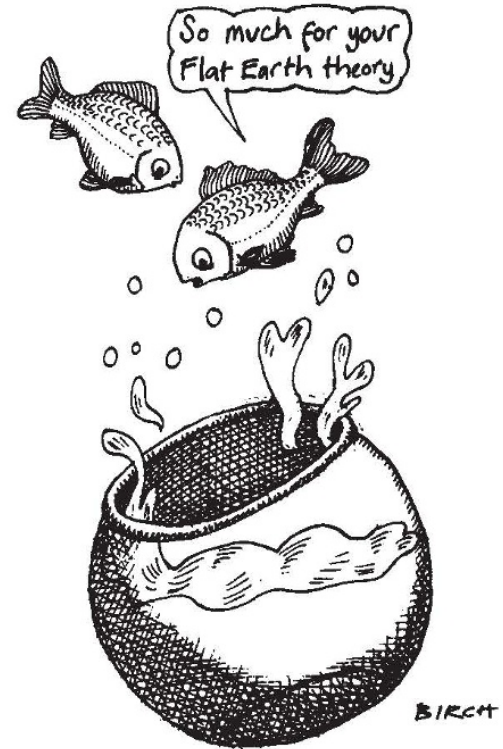

The Japan Microgravity Center in Kamisunagawa was built for several tens of millions of dollars with the support of the local government, private companies and MITI's New Energy and Industrial Technology Development Organization. It will be rented out for microgravity experiments to develop new materials and for the high-purity separation of cells and proteins.

David Swinbanks by the agreement - information sciences, manufacturing and process control, geosciences, joint database development, advanced materials and life sciences. Among the most significant agreements was a decision to set up a joint US-Japan panel on volcano disaster prevention, an agreement spurred in part by the recent eruptions at Mount Unzen in Japan and Mount Pinatubo in the Philippines. The lifesciences liaison group also came to an agreement on how to divide roles between the United States and Japan in the human genome project.

There was no substantial agreement, however, on proposed collaborations in big science. The US delegation repeated US hopes that Japan will make a large financial contribution to construction of the US Superconducting Super Collider, and the Japanese responded by repeating views expressed a week earlier by Prime Minister Toshiki Kaifu to President George Bush (see Nature 352, 177; 18 July 1991). They said that Japan is struggling to rehabilitate its national universities and cannot say anything about a financial contribution to the project at this stage. This is about as close as Japanese diplomacy ever comes to saying no.

Japan's proposed Intelligent Manufacturing System project, a project to develop the automated factories of the future, remains up in the air waiting for the US Department of Commerce to propose terms of reference for an international feasibility study. Similarly, Japan is waiting for the same US department to propose how (and whether) with collaboration in Japan's planned sixth-generation computer project.

US officials told Japan that the United States cannot make any substantial financial contribution to Japan's Human Frontier Science Programme until at least 1993.

Japan expressed concern about the uncertainty surrounding the US Space Station project, in which Japan is committed to invest hundreds of millions of dollars to build a Japanese module for the station. US officials said there is still strong support in the US Congress and Administration for the project and Japan should not worry about a recent vote by a committee of the House of Representatives to terminate the budget for the station. The vote, although later overruled by the full House, shook Japan and may have killed any hope of a Japanese contribution to the Superconducting Super Collider.

In the light of these problems, both sides agreed that consultation in the early stages of proposed projects is essential for successful collaboration in big science.

David Swinbanks

\section{AIDS in Yanomami?}

\section{Sao Paulo}

THE Brazilian press reported last week that a Yanomami woman has died of AIDS and that others of the Indians showed antibodies against human immunodeficiency virus. The Yanomami are the largest tribal group in the Americas that is still relatively free of contact with settlers. There are about 20,000 of them, roughly divided between Brazil and Venezuela.

Although the Brazilian government has denied the report, insisting that the woman belonged to another tribe and that the reports of antibodies were caused by misunderstandings, it is undeniable that the Yanomami could have been exposed to AIDS via the 10,000 gold miners who have come into their lands and brought malaria and venereal disease.

Between January and June, 62 Indians died from these diseases in the state of Roraima, near the Venezuelan border, where many of the miners are.

Last week, Brazilian federal police and FUNAI, the Indian protection agency, began to expel the miners from the lands of the Yanomami, in the state of Roraima. But it will be too late for some of the Yanomami.

\section{Ricardo Bonalume}

\section{Atomic lab flooded}

\section{Bombay}

THE Bhabha Atomic Research Centre (BARC) in Bombay is struggling to recover from damage caused by muddy rain water that entered the basement of a halfkilometre-long laboratory block, ruining valuable equipment. The Modular Laboratory is BARC's main building, with offices on the upper floors and laboratory facilities in the basement. On 8 June, after unprecedented monsoon rain and a landslide from an adjoining hill, the building's entire basement was under two-and-half feet of water mixed with mud.

The list of equipment damaged includes an electron linear accelerator imported from Britain, several spectrometers and a uranium laser separator used to produce 30 per cent enriched uranium.

R. Chidambaram, director of BARC, estimated the loss at Rs5 million, but unofficial sources put it at not less than Rs100 million. Chidambaram said that half of the damaged equipment had already been salvaged and that all the facilities would be brought back into operation in two months. Some senior scientists at BARC, however, dismiss this claim as unattainable. Many pieces of equipment are beyond repair because of sand inside sensitive components, and there is a general feeling that research in at least some divisions will be set back by two or three years.

K. S. Jayaraman 